\title{
Prevalence of HIV-infection in Saudi Arabia
}

\author{
AF Alothman ${ }^{1,2^{*}}$, K Mohajer $^{1}, \mathrm{H}$ Balkhy ${ }^{2,3}$ \\ From International Conference on Prevention \& Infection Control (ICPIC 2011) \\ Geneva, Switzerland. 29 June - 2 July 2011
}

\section{Introduction / objectives}

Human immunodeficiency virus infection prevalence in Saudi Arabia was shown to be $0.02 \%$ in previous study. Following the annual incidence of HIV-infection can evaluate the degree of change in incidence of infection.

\section{Methods}

Obtaining the correct data from the National AIDS Program at Saudi Ministry of Health according to the annual report of HIV-positive patients.

\section{Results}

Between 1984 and 2001, it was found that 1285 HIVpositive cases were Saudis averaging 76 new cases per year. The reported HIV-positive person at the end of 2004 was 2005 cases. The rate of annual incidence of HIV-infection in Saudis was ranging 229-505 cases per year on 2001 - 2009. Between 2001 and 2009 the mean annual incidence of HIV-infection in Saudis was 342 cases per year. The last 8 years the new HIV infection in Saudis was 2734 cases only between early 2002 and end of 2009. The total number of HIV-positive Saudis on early 2010 was 4019 persons.

\section{Conclusion}

During the last 8 years showed significant annual increase in the number of HIV-infected people in Saudi Arabia. This cumulative increase will require better policies to deal with such rising incidence of HIV-infection.

\section{Disclosure of interest}

None declared.

\section{Author details}

${ }^{1}$ Medicine Department, King Abdulaziz Medical City, Riyadh, Saudi Arabia. ${ }^{2}$ College of Medicine, KSAU-HS, Riyadh, Saudi Arabia. Infection Prevention and Control, King Abdulaziz Medical City, Riyadh, Saudi Arabia.

${ }^{1}$ Medicine Department, King Abdulaziz Medical City, Riyadh, Saudi Arabia Full list of author information is available at the end of the article
Published: 29 June 2011

doi:10.1186/1753-6561-5-S6-P252

Cite this article as: Alothman et al:: Prevalence of HIV-infection in Saudi Arabia. BMC Proceedings 2011 5(Suppl 6):P252.
Submit your next manuscript to BioMed Central and take full advantage of:

- Convenient online submission

- Thorough peer review

- No space constraints or color figure charges

- Immediate publication on acceptance

- Inclusion in PubMed, CAS, Scopus and Google Scholar

- Research which is freely available for redistribution

\section{Ciomed Central}

